\title{
Challenges in Teaching Pronunciation in Malaysian Secondary Schools: Novice Teacher's Perspective
}

\author{
Norbazila Mohd Asikin \\ Sekolah Menengah Batu Kikir, Jempol, Negeri Sembilan, Malaysia \\ Noor Aireen Ibrahim* \\ Language Academy, Faculty of Social Sciences and Humanities, Universiti Teknologi Malaysia, 81310 UTM \\ Johor Bahru, Johor, Malaysia
}

Submitted: 29/09/2020. Revised edition: 29/11/2020. Accepted: 29/11/2020. Published online: 30/12/2020

\begin{abstract}
Pronunciation is a key component of speaking skill and providing students with sufficient knowledge on correct pronunciation will help to improve their overall speaking skills. However, pronunciation remains a contentious issue in English as a Second Language (ESL) teaching and learning process as teaching pronunciation has often been avoided by language teachers. There are many factors that make teaching pronunciation a challenge for teachers and can be divided into internal and external challenges. This study was conducted to examine challenges faced by teacher trainees in teaching pronunciation and ways in which these challenges were managed. This study employed both quantitative and qualitative methods of data collection. A set of self-developed questionnaire with two main sections and a total of eight items was distributed to 34 teacher trainees, six of whom were interviewed to gather data for this study. Challenges in teaching pronunciation found in this study can be divided into two categories which were internal and external challenges. Internal challenges consist of i) lack of confidence, ii) lack of sufficient knowledge and iii) pedagogical issues. On the other hand, external challenges faced by novice teachers in this study included i) lack of priority, ii) limitation of time; and iii) lack of teaching materials and resources. Although novice teachers face both internal and external challenges in teaching pronunciation, three main methods were employed by the respondents to manage these challenges. The management of these challenges showed that novice teachers were aware of the importance of teaching pronunciation and therefore did not allow these challenges to become a barrier.
\end{abstract}

Keywords: Pronunciation, ESL, internal challenges, external challenges, teacher trainees

\section{INTRODUCTION}

Pronunciation is a subskill of speaking (Gilakjani and Mohammad Reza, 2011) and is considered a priority for English as Second Language (ESL) students (Priya and Kumar, 2020) Students who can pronounce English words correctly, will help them to improve their speaking skills. However, according to Fraser (2000), the ability to communicate in English among students in schools remains

\footnotetext{
*Correspondence to: Noor Aireen Ibrahim (email: naireen@utm.my)
} 
a problem even after learning the language for many years. This is unsurprising as the teaching of pronunciation remains a contentious issue as teaching pronunciation has often been avoided by language teachers (MacDonald, 2002). In terms of whether it is important to teach and learn pronunciation in the English classroom, teachers and students agree that it is one of the crucial components that need to be taught by teachers and learned by students (Jayapalan and Pillai, 2011). However, in most cases, students have the tendency to not partake in classroom activities when English pronunciation is taught in the classroom because students often feel that their pronunciation is deficient (Barrera, 2013).

In Malaysia, the teaching of pronunciation as stated in the 2003 Malaysian English Curriculum Specification includes the teaching of the sound system which covers consonants, vowels, plural forms and contractions. Several phonemes are given as references for teachers when conducting the activities in the English classroom. However, the English Language textbook does not provide audio resources for both students and teachers. This means that the classroom teaching of pronunciation, if it takes place, depends totally on the input from the ESL teacher. Although the teaching of pronunciation is stated in the curriculum specification, it appears that the explicit teaching of pronunciation has not been given emphasis (Derwing and Munro 2005, Algahazo, 2015). This is true of many ESL classes or programs.

One of the main contributing factors for the lack of emphasis on teaching pronunciation is the lack of knowledge teachers have on how to teach pronunciation due to the absence of a clear and systematic guide for teachers (Derwing, Diepenbroek, \& Foote, 2012, Derwing and Foote, 2011; M. Lekha Swarna Priya, Prasantha Kumar, 2020). Similarly, Scrivener (2005) indicated that teachers are reluctant to produce lesson plans for teaching pronunciation because they feel that they do not have the knowledge needed to teach their students. In fact, several studies (e.g. Nair, Krishnasamy and De Mello, 2006) have shown that ESL teachers are actually not properly trained for teaching pronunciation to their students. Although teachers are taught phonology in their teacher training program, little focus is given on how to teach pronunciation in the classroom. The lack of training received by teachers is the prevailing reason why teachers tend to avoid teaching pronunciation in the ESL classroom.

Another reason why pronunciation has not been given due emphasis is because of the perceived importance associated to pronunciation. Studies have indicated that teachers have a tendency to overlook pronunciation teaching as it is the least functional of the other language skills. In fact, teachers usually forfeit teaching pronunciation while focusing more on the other language skills (Elliot, 1995). Furthermore, the lack of emphasis on pronunciation teaching can be attributed to an exam-oriented school system. Unlike the other skills, pronunciation is not being questioned in examinations and therefore is not prioritized (Brindley, 1998). Pillai (2008) also mentioned that pronunciation is being ignored because teachers are too preoccupied with dealing with other skills and preparing students for examination.

For teachers who do include the teaching of pronunciation in their lesson plans, reading aloud activity is the most preferred approach by the teachers in teaching pronunciation (Jayapalan and Pillai, 2011). They will ask the students to read a chosen text, when teachers notice students are making mistakes in pronouncing the words, they will correct the students on the spot. This is 
commonly practiced in the English classroom in which pronunciation teaching seems to be embedded in the language teaching. In other words, English teachers rarely dedicate a whole lesson to specifically teach pronunciation. However, the problem is that this activity is not frequently carried out because teachers focus on other components of English such as grammar and writing skill.

There are many problems that make teaching pronunciation a challenge for teachers and can be divided into two which are internal and external challenges (Hayati, 2008). Internal challenges consist of lack of confidence (Fraser, 2006), lack of knowledge (Egwuogu, 2012) and pedagogical issue (Darcy et al., 2011). On the other hand, external challenges are time constraint (Baker, 2011), lack of priority (Machackova, 2012) and lack of teaching materials and resources (Brown, 1992).

From the discussion thus far, it is difficult to deny the importance of teaching English pronunciation to students in schools. However, it can be very challenging even to students who have been introduced to English language for many years (Gilakjani and Mohammad Reza, 2011). According to Morley (1991), the most crucial element of communication competence is intelligible pronunciation. Therefore, if teachers continue to neglect the teaching of pronunciation, students' communicative competence may be affected. In other words, without proper pronunciation training, students' verbal intelligibility may be affected and therefore their communicative competence may be impaired. Therefore, this study is conducted in order to investigate the challenges ESL teacher trainees face in teaching pronunciation and how these novice teachers manage the challenges during their practical teaching. This study is conducted in the hope that the findings will be able to shed light on the importance of teaching pronunciation and preparing novice teachers or teacher trainees to teach pronunciation once they become full-fledged language teachers.

\section{LITERATURE REVIEW}

In light of the objectives and aims of this study, key research in relevant areas which underpins the current study will be discussed in the ensuing sections.

\section{Teaching English as a Second Language (TESL) and Pronunciation}

In any language, the sounds produced in a particular language carries meaning. Therefore, the way words are pronounced is very important since misinterpretation may occur if words are pronounced the wrong way. There are two main elements in English pronunciation which are phonetics and phonology. According to Gut (2009), phonetics is related to the production, properties and perception of the speech sounds of human languages. On the other hand, phonology explains how patterns in a particular language can be formed from these speech sounds. These two elements are important in language teaching because phonetics illustrates the distinctiveness of individual speech sounds specifically and phonology clarifies the patterns which exist in those speech sounds (Rogerson-Revell, 2011).

Segmental and supra-segmental aspects have the major influence in getting the meaning of a word for English language (Muhammed and Taha, 2014). An individual who is good at pronouncing English 
words may make grammatical errors, but this may not impede the message and thus may still avoid the occurrence of misunderstanding in communication. On the other hand, an individual whose speech is grammatically accurate but have pronunciation issues will likely face communication problems when interacting with others. Therefore, we know that the importance of pronunciation is related to another part of English language which means that pronunciation skill is as crucial as other language skills.

Figure 1.1 illustrates the elements of English pronunciation that are divided into two main group, segmental and suprasegmental. Both of these elements are important in English pronunciation (Fraser, 2000).

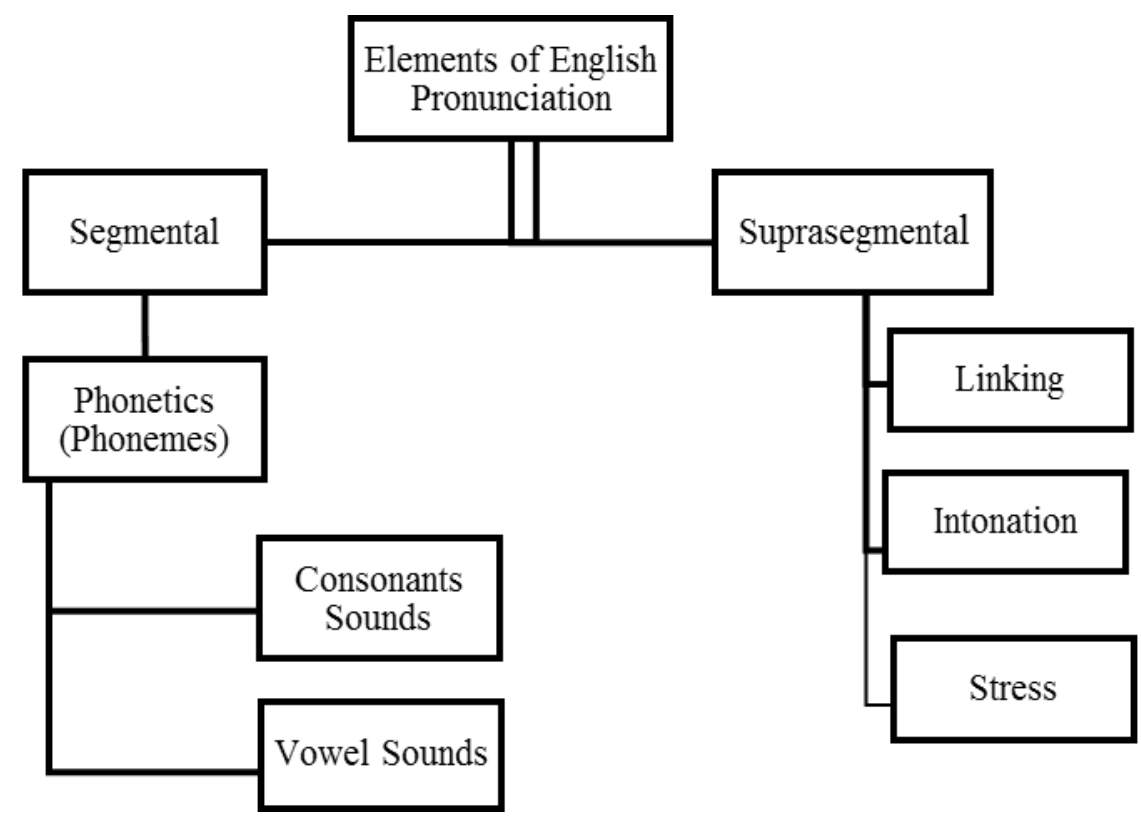

Figure 1.1 The elements of English pronunciation (Gilakjani, 2012)

Based on Figure 1.1, vowels and consonants are the elements in segmental feature. These are the two elements that complement each other in composing a speech. It is quite easy for the students to comprehend segmental features since it deals with the sounds. According to Ballard (2013), segmental phonology is related to the distribution of the phonemes, explanation on how the phonemes differ in different surroundings, and how phonemes set together to create syllables and words.

\section{Challenges in Teaching Pronunciation}

Several challenges in teaching pronunciation have been identified by previous studies. These challenges can be divided into two which are internal and external challenges (Hayati A. Majid, 2008). The internal challenges can be defined as the inner factors that come from an individual and can 
influence the teaching of pronunciation. On the other hand, the external challenges are the outer factors that could affect the teaching of pronunciation in the classroom.

\section{Internal Challenges in Teaching Pronunciation}

\section{i) Lack of Confidence}

In teaching pronunciation, language teachers often lack confidence in pronouncing certain words. Teachers are concerned about teaching students the wrong pronunciation. In fact, teachers need to realize that pronunciation is not just about mental activity in which the students have to recognize the sounds, it is also a physical skill which requires practice (Fraser, 2006). Notably, teachers' prior beliefs and experiences of learning have a direct influence on the future teacher judgments and decision making in their actual teaching practices (Mak, 2011, Farrell \& Yang, 2017) As such, the other challenge often encountered by ESL teachers when teaching pronunciation is their tendency to relate their own personal experience of learning pronunciation during their teacher training with teaching pronunciation at school (Gilbert, 2008). Teachers often find the phonetics course they went through quite challenging and even difficult, and thus feel reluctant to teach pronunciation to their own students. Many teachers fail to realize that teaching pronunciation to school students is not the same as learning phonetics at the tertiary level. Tertiary level phonetics courses can be considered specialist courses and thus can be very technical and is very different to what is taught at schools. Teachers will have to vary the teaching approach by simplifying the learning of pronunciation according to the students' English Language proficiency level and needs.

\section{ii) Lack of Knowledge and Training}

Apart from the lack of confidence, another common challenge in teaching pronunciation is the knowledge about teach pronunciation. This problem might be influenced by the mother tongue of the ESL teachers. Some teachers have problems in using the correct intonation and stress when they speak the language which will impact the delivery of teaching in the classroom (Egwuogu, 2012). Thus, preparation as a language teacher is essential to ensure that complex language skills are taught in a way that is easy for students to comprehend and master - this requires proper planning and preparation. In addition, studies have indicated that teachers actually do not know how to teach pronunciation effectively to students. For example, Fraser (2000) explained that most ESL teachers are not disinterested to teach pronunciation but that they are actually in doubt as to how they can actually help students to effectively learn pronunciation. Similarly, Couper (2017) revealed that lack of prior knowledge and training of pronunciation teaching raised doubts about what and how to teach in the classroom conducted This finding was gathered through semi-structured interviews with 19 English Language teachers in New Zealand. 
In addition, teachers find it difficult to give instruction when they teach pronunciation to the students. This problem causes them to avoid teaching pronunciation in the classroom (Darcy et al., 2011). Giving clear instructions is one of the most important skills in teaching as students need to understand what they need to do to participate in the activity conducted by the teachers. This is especially so if the students have had little or no exposure to pronunciation.

In terms of teaching materials, it is better if teachers can provide students with real audio recording so that students can listen and practice the spoken language with their friends in the classroom. Previous studies have shown that students at schools do not have enough exposure in experiencing real life conversation using English language (Ndung'u, 2013). By not giving students enough practice speaking on their own, it will bequite challenging for them to speak since they might feel insecure and uncomfortable to speak using the language. Therefore, authentic spoken English material can help to promote the teaching and learning process of pronunciation in the classroom.

\section{External Challenges in Teaching Pronunciation}

Apart from teaching, teachers have other responsibilities such as carrying out administrative duties, attending meetings, managing students' file, monitoring students' progress, organising and attending co-curriculum activities. All these responsibilities take a lot of time and it is unsurprising that time constraint is another challenge that the teachers faced in teaching pronunciation to the students (Baker, 2011). In the same vein, Georgios (2019), in his study involving 98 Greek-Cypriot EFL teachers, indicated that time constraint was an important reason that there is a low interest in teaching pronunciation in classrooms. Instead of spending time teach pronunciation in, teachers may prefer to teach other English components which benefits the students in the examination. This is especially true in an exam-oriented school system. Pronunciation teaching requires the teachers to carefully plan the lesson and prepare suitable materials according to students' proficiency level. This preparation can often be time consuming time - time better spent on lessons for skills which will be tested in examinations.

\section{ii) Lack of Priority}

Despite the importance of having good pronunciation to ensure effective communication, the teaching of pronunciation is still not being prioritized at schools (Machackova, 2012). When teachers find it challenging to produce a lesson on pronunciation practice only, they take pronunciation as one of the additional topic that is not compulsory to teach. Furthermore, the goal of learning English language is just to pass an examination that all students are aware that it does not include oral pronunciation test in it. Most schools emphasize more on academic achievement rather than what the students have learned and what skills they have acquired. When this awareness is not instilled in these students, it 
could affect the teaching of pronunciation in the classroom. When students are not interested to learn, the teachers might feel not motivated to keep up with the teaching. That is why the teachers' focus has been changed where they start to emphasize on the components that will be tested in the examination. The teachers are just training the students with the aim of obtaining a good grade for English.

In order to ensure language teachers become good at teaching pronunciation to the students, emphasis needs to be given early during the teacher training period. The specific course such as phonetics and phonology should be taught specifically to the trainee teachers so that they master the adequate knowledge in these courses. With that, they will be able to practice what they have learned when they become a language teacher. Some studies have shown that although trainee teachers have been trained to teach pronunciation and therefore have been equipped with the knowledge to teach pronunciation to the students at schools, they still have problems teaching it in schools (Jayapalan and Pillai, 2011). Interestingly, according to Nair, Krishnasamy and De Mello (2006), trainee teachers tend to put less time and effort in preparing for pronunciation lesson if compared to other components of English. This in itself can affect their ability to teach pronunciation at schools.

It has also been argued that the training given to the trainee teachers is not enough to ensure that they would be able to teach effective lesson to the students (Breitkreutz et al., 2001). This issue also address that it is a must for the trainee teachers to have proper training in pronunciation especially in these two courses, Phonetics and Phonology. By mastering these two courses, at least the trainee teachers have the right input to be delivered to the students during the process of teaching and learning in the classroom (Shahzada, 2012).

\section{RESEARCH OBJECTIVES AND RESEARCH QUESTIONS}

Based on the discussion thus far, this study aims to answer the following Research Objectives (RO) and Research Questions (RQ):

RO 1: To investigate the challenges faced by teacher trainees in teaching pronunciation.

RQ 1: What are the challenges faced by TESL teacher trainees in teaching pronunciation?

RO 2: To determine how the challenges in teaching pronunciation are managed by teacher trainees.

RQ 2: How are these challenges in teaching pronunciation managed by TESL teacher trainees? 


\section{RESEARCH METHODS}

In order to examine the challenges faced by teacher trainees in teaching pronunciation, a mixedmethod approach was undertaken in this study. Both quantitative as well as qualitative data were gathered and analysed in this study. In the following sections, the methodological approach taken by this study will be discussed in detail.

\section{Respondents of the Study}

Two groups of respondents were chosen for this study: i) 17 third-year students in the Teaching English as a Second Language (TESL) bachelor's degree program who were currently undertaking their practical teaching in different Malaysian secondary schools; and ii) 17 fourth year TESL students who have completed their practical teaching in schools. Both groups of respondents were selected because of the teaching experience they have as teacher trainees. The respondents have taught students at schools and for that reason, they would be able to provide feedback on their experience teaching pronunciation in schools. Their experience in practical teaching will benefit this study as they will be able to share their thoughts and experiences especially regarding teaching pronunciation to the students.

\section{Research Instruments}

This study employed both quantitative and qualitative methods of data collection which were questionnaire and interview. A set of self-developed questionnaire with two main sections and a total of eight items were used in collecting data for this study. Table 1.1 illustrates the main parts of the questionnaire.

Table 1.1 Questionnaire Items

\begin{tabular}{lllc}
\hline Part & Specification & Items & $\begin{array}{c}\text { Research } \\
\text { Question }\end{array}$ \\
\hline A & $\begin{array}{l}\text { Background Information } \\
\text { of Respondents }\end{array}$ & Item 1 and 2 & - \\
& $\begin{array}{l}\text { Challenges in Teaching } \\
\text { Pronunciation: } \\
\text { i. Internal Challenges } \\
\text { ii. External Challenges }\end{array}$ & $\begin{array}{l}\text { Item 1 until 3 } \\
\text { Item 4 until 6 }\end{array}$ & RQ 1 \\
& & & \\
\hline
\end{tabular}


The first section of the questionnaire aimed at gathering the background information of the respondents. While the second section of the questionnaire was designed to obtain information on challenges faced in teaching pronunciation in school. Respondents were asked to indicate their agreement to the statements in a five-point Likert scale which ranged from Strongly Agree (SA), Agree (A), Undecided (U), Disagreed (DA) and Strongly Disagreed (SD). In addition, interviews were conducted using eleven semi-structured questions. Table 1.2 outlines the different questions asked during the interview and how they relate to the research questions.

Table 1.2 Interview Questions

\begin{tabular}{lll}
\hline Part & Specification & $\begin{array}{l}\text { Research } \\
\text { question }\end{array}$ \\
\hline A & Follow-up questions & - \\
& $\begin{array}{l}\text { Challenges in Teaching Pronunciation: } \\
\text { i. Internal Challenges } \\
\text { ii. External Challenges }\end{array}$ & RQ1 \\
B & $\begin{array}{l}\text { Managing Teaching Pronunciation } \\
\text { Problems? }\end{array}$ & RQ 2 \\
C &
\end{tabular}

These questions focused on the internal and external challenges faced by respondents with an emphasis on how respondents address and manage these challenges when teaching pronunciation. Interview sessions were conducted with six respondents - three were third year students while the other three were selected from the fourth-year students. All six respondents were randomly selected.

\section{Pilot Study}

A pilot study was carried out in order to assess the reliability of the questionnaire as well as the interview questions in addressing the research questions outlined in this study. In addition, it was also to ensure that the questionnaire and interview questions were clear and comprehensible to the respondents. Five TESL students were given the questionnaire and were interviewed in the pilot study. After receiving responses from the respondents, modifications were carried out to further improve the clarify of the questions. The modifications were mostly on the suitability of word choice used in the questionnaire and interview questions.

\section{FINDINGS AND DISCUSSION}

In the following sections, the findings that have emerged from the analysis of both quantitative and qualitative data will be discussed. 


\section{Challenges Faced by TESL Teacher Trainees in Teaching Pronunciation}

Challenges in teaching pronunciation found in this study can be divided into two categories which are internal and external challenges. Internal challenges are the factors that come from the teacher trainees themselves that may affect the teaching of pronunciation in the classroom. Based on the findings, it is clear that the majority of the respondents faced challenges in teaching pronunciation during their practical teaching. With regard to internal challenges, there were mixed responses for two of the challenges which were i) lack of confidence and ii) lack of sufficient knowledge. The respondents agreed that they faced problems related to pedagogical issues during their practical teaching. Table 1.3 shows the internal challenges faced by novice teachers in this study gathered from the questionnaires as well as the interviews conducted.

Table 1.3 Internal Challenges Faced by Teacher Trainees

\begin{tabular}{|c|c|c|c|c|}
\hline Challenges & \multicolumn{3}{|c|}{ Questionnaire (\%) } & Interview \\
\hline & Agree & Undecided & Disagree & Challenges faced by the respondents \\
\hline $\begin{array}{l}\text { Lack of } \\
\text { confidence }\end{array}$ & 43 & 16 & 41 & 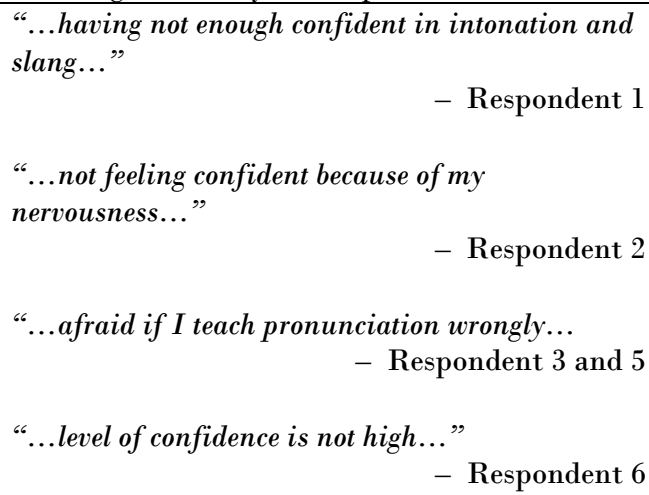 \\
\hline $\begin{array}{l}\text { Lack of } \\
\text { sufficient } \\
\text { knowledge }\end{array}$ & 38 & 29 & 33 & 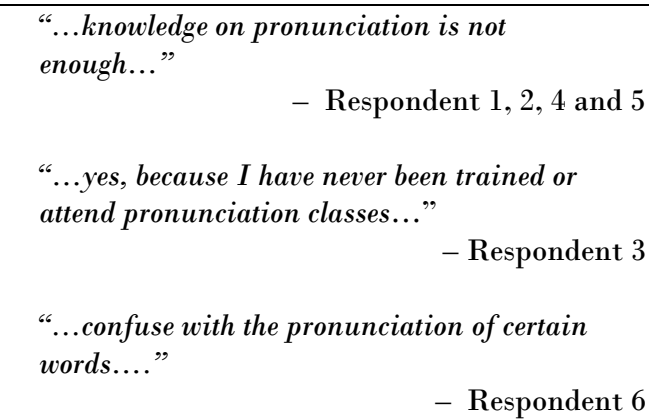 \\
\hline $\begin{array}{l}\text { Pedagogical } \\
\text { issues }\end{array}$ & 41 & 21 & 38 & $\begin{array}{l}\text { "...it was quite hard to teach the right } \\
\text { intonation..." } \\
\text { “...even I repeat the words for several times, the } \\
\text { students still cannot get it right..." } \\
\quad \text { - Respondent } 2\end{array}$ \\
\hline
\end{tabular}


The first internal challenge is the lack of confidence. The number of respondents who agreed and disagreed were quite balanced with $43 \%$ who agreed and $41 \%$ disagreed. The teacher trainees in this study appear to be shadowed by their experience in learning pronunciation during their undergraduates training. The teacher trainees may have experienced difficulties in learning phonetics and therefore is reluctant to teach pronunciation to their students. This is supported by previous study (e.g. Gilbert 2008, Mak 2011 and Farrell \& Yang, 2017) which showed that the lack of confidence among teacher trainees can be attributed to their past experiences in learning pronunciation. Furthermore, the teacher trainees may be afraid of mispronouncing certain words during the process of teaching and learning and this is evident in the interview data in which several respondents admitted that they were worried about intonation (Respondent 1) and "teach pronunciation wrongly" (Respondent 3 and 5). In addition, several studies (e.g. Fraser2002, Couper 2016) have indicated that the training received by teacher trainees may have an impact on their confidence level to teach pronunciation. According to Fraser (2002), Novice teachers were still not assured of their ability to teach pronunciation because they may have not received sufficient knowledge on speech and pronunciation. This is especially true for ESL learners and perhaps for nonnative TESL teachers as well.

Closely related to the issue of teacher training is the second type of challenge faced by the respondents in teaching pronunciation that is the lack of sufficient knowledge. According to Egwuogu (2012), incorrect intonation and stress during the process of delivering the knowledge to students could lead to misunderstanding of the lesson's content. Therefore, clear communication between the teacher and students is very crucial and trainee teachers must be given proper pronunciation training to ensure clear communication. It is interesting to note that the majority of the respondents in this study agreed (38\%) that they had sufficient knowledge. In contrast, $33 \%$ felt that they had insufficient knowledge. An almost equal number of the novice teachers (29\%) were undecided. The rather indefinite figures received for this item is not surprising as the findings suggest that novice teachers are actually dealing with several challenges in teaching pronunciation. One possible reason for this could be that the respondents who admitted to having sufficient knowledge may not know how to apply it in the classroom.

The third internal challenge faced by the respondents relates to pedagogical issues. The findings in this study clearly showed that the majority of the respondents agreed that this is indeed a problem they faced during their practical teaching. Teaching pronunciation will require teachers to demonstrate the right pronunciation to students. However, by focusing on providing correct pronunciation, sometimes teacher might give unclear instruction to the students (Varasarin, 2007). Teachers cannot depend only on the recording of native speakers in delivering the instruction during the learning process. This is simply because they have different accent and culture which may not be suitable for the students in the Malaysian classroom setting. Ndung'u (2013) also mentioned that students at schools might have little practice in using English language in their daily life which makes it difficult for them to listen and understand to any English conversation in the classroom.

Apart from that, the respondents in this study also faced external challenges in teaching pronunciation to the students. Three main external challenges faced by novice teachers in this study are i) Priority issues, ii) Lack of time and iii) Lack of teaching material and resources. Table 1.4 shows 
the external challenges faced by novice teachers in this study gathered from the distributed questionnaires as well as the interviews conducted.

Table 1.4 External challenges faced by novice teachers

\begin{tabular}{|c|c|c|c|c|}
\hline Challenges & & Iestionnaire & & Interview \\
\hline & Agree & Undecided & Disagree & Challenges faced by the respondents \\
\hline Priority issues & 41 & 18 & 41 & $\begin{array}{r}\text { "...in schools, priority is to effectively } \\
\text { prepare a lesson to fulfill the syllabus..." } \\
\text { - Respondent } 3\end{array}$ \\
\hline Lack of time & 44 & 15 & 41 & $\begin{array}{l}\text { "...time constraint for teaching } \\
\text { pronunciation..." } \\
\qquad- \text { Respondent } 2 \\
\text { “...having not enough time to prepare } \\
\begin{array}{l}\text { lesson..." } \\
\text { - Respondent } 3\end{array}\end{array}$ \\
\hline $\begin{array}{l}\text { Lack of } \\
\text { teaching } \\
\text { material and } \\
\text { resources }\end{array}$ & 51 & 23 & 26 & $\begin{array}{l}\text { “...facing facilities problem..." } \\
\qquad \text { Respondent } 1 \text { and } 4 \\
\text { “...difficult to find suitable teaching } \\
\text { material on pronunciation..." } \\
\text { - Respondent } 2 \text { and } 6 \\
\text { “...teaching materials and resources are } \\
\text { limited..." - Respondent } 3\end{array}$ \\
\hline
\end{tabular}

Teaching pronunciation does not seem to be prioritized in the syllabus of English language for secondary school students. As such pronunciation is only placed as a sub-skill under the speaking skill. Often teacher trainees assume that teaching pronunciation is not as important as other components of the English language (Varasarin, 2007; Grim and Strum, 2016). Therefore, it is not surprising that an equal number of respondents $(41 \%)$ in this study both agreed and disagreed that teaching pronunciation is not the priority in the Malaysian English syllabus. The findings may indicate that novice teachers are themselves unsure about the importance given to pronunciation in the Malaysian syllabus. The novice teachers may be aware of the importance of pronunciation but may be confused by the lack of priority given in the Malaysian English syllabus. This is supported by Machackova (2012) who stated that teaching pronunciation is still not being prioritized at school as teachers tend to focus on the elements that are being tested in examinations (Gilbert, 2008).

Another external challenge faced by the respondents was the limitation of time (Baker, 2001). The findings in this study is interesting since there is a corresponding number of respondents who agreed 
$(44 \%)$ and disagreed $(41 \%)$ that limitation of time was a challenge in teaching pronunciation. This corresponds to previous studies (e.g. Baker, 11; Georgios, 2019) which has shown time constraints as an important challenge in teaching pronunciation. Acquiring correct pronunciation requires more time and more practice. Therefore, spending only 70 minutes on teaching pronunciation is never enough for a teacher. Majority of the respondents did not teach pronunciation as an entire lesson. Teachers often integrate pronunciation skills into other lessons. For example, while teaching reading comprehension, teachers will include pronunciation skills in the lesson by demonstrating the correct pronunciation with the students through reading aloud activity (Jayapalan and Pillai, 2011). Furthermore, class size can also be a challenge, with 40 to 45 students, it may not be possible for a teacher to assess each and every student's pronunciation skill. Therefore, it can be quite challenging for teacher trainees to teach pronunciation to the students in a short period of time (Darcy et al., 2011). Although there is a plethora of pronunciation resource available online, selecting the most appropriate ones can be a daunting task as well as time consuming for teachers especially for teachers who are not trained in ESL pronunciation instruction.

Lack of teaching materials and resources is the third type of external challenge faced by the respondents in this study. Based on the findings, the majority of respondents $(51 \%)$ agreed that it is quite hard to search for suitable teaching material that suits the students' proficiency level. Although the English textbook includes a section on phonics that highlights certain vowel and consonant sounds, it is not provided for all topics in the textbook. The information provided in the textbook appear to lack detail and consists of very brief explanation which may not be sufficient for the students and teachers in the process of teaching and learning pronunciation in the classroom. In addition, although there is an accompanying CD- ROM provided for teachers but due to the lack of proper facilities such as LCD projector and white screen, the CD-ROM in many government schools, this may be difficult to be used for classroom teaching purposes. Furthermore, few schools have proper language labs for pronunciation teaching. By having effective and suitable teaching material, it will enhance the learning process, and this is supported by Brown (1992) who has shown that the lack of teaching material can have an impact on the effectiveness of teaching pronunciation to students.

\section{Managing Internal and External Challenges in Teaching Pronunciation at School}

Apart from identifying the challenges faced by the respondents in teaching pronunciation during their practical teaching, this study also examined ways in which respondents manage these challenges. Table 1.5 shows the thematic analysis on managing internal challenges among the respondents. 
Table 1.5 Managing internal challenges in teaching pronunciation

\begin{tabular}{|c|c|c|}
\hline $\begin{array}{l}\text { Internal challenges faced by the } \\
\text { respondents }\end{array}$ & $\begin{array}{l}\text { Methods used in } \\
\text { managing the } \\
\text { challenges }\end{array}$ & Summary of the response \\
\hline $\begin{array}{l}\text { Lack of knowledge } \\
\text { - Confusion in pronouncing the words } \\
\text { correctly }\end{array}$ & - Seek help & $\begin{array}{l}\text { - Asking help from mentor } \\
\text { - Referring to offline dictionary in mobile } \\
\text { phone } \\
\text { - Watching related videos on YouTube and } \\
\text { listening to English songs }\end{array}$ \\
\hline $\begin{array}{l}\text { Lack of confidence } \\
\text { - Afraid of making mistake to pronounce } \\
\text { the words properly }\end{array}$ & $\begin{array}{l}\text { - Prepare and } \\
\text { plan for } \\
\text { lesson }\end{array}$ & $\begin{array}{l}\text { - Confirming the correct pronunciation of } \\
\text { words before class }\end{array}$ \\
\hline $\begin{array}{l}\text { Pedagogical issue } \\
\text { - Students' reluctance to speak during } \\
\text { the learning process } \\
\text { - Pronunciation practice } \\
\text { - Students inability to follow the } \\
\text { pronunciation lessons }\end{array}$ & $\begin{array}{l}\text { - Devise } \\
\text { strategies to } \\
\text { assist } \\
\text { students }\end{array}$ & $\begin{array}{l}\text { - Having one-to-one session with the } \\
\text { students } \\
\text { - Selecting students randomly so that they } \\
\text { come prepared } \\
\text { - Monitoring the students one by one during } \\
\text { the practice } \\
\text { - Setting a rule on speaking only English } \\
\text { during English lessons. } \\
\text { - Using interesting and integrating suitable } \\
\text { videos in the lesson } \\
\text { - Conducting more group activities }\end{array}$ \\
\hline
\end{tabular}

It is clear form Table 1.5 that there are three main themes in managing the internal challenges faced by novice teachers in teaching pronunciation to students at schools: i) seek help, ii) prepare for lesson; and iii) devise strategies to assist students. Respondent 1 preferred to seek help from her mentor at school if she faced any problem in teaching pronunciation. In fact, Respondent 1 would try to find the solution to her problem before seeking help from others. She believed that by having oneto-one sessions with the students will help them to better improve their pronunciation. Similarly, Respondent 2 believed that by monitoring each student's pronunciation skill will help students to progress. She would randomly select students for pronunciation activities. This helps to encourage students to come prepared and take the initiative to pronounce the new or difficult words during the classroom discussion and practice.

On the other hand, Respondent 3 preferred the use of interesting teaching materials for her pronunciation lessons, for example, the use of interesting videos on teaching pronunciation. In addition, preparation is also important as she will make sure her pronunciation of words involved in the lesson is correct before she enters the classroom. Similarly, Respondent 4 also incorporated technology in her lessons by using offline dictionary if she encountered problems in pronouncing any words in the classroom. She also preferred to correct her students' pronunciation during classroom activities. Like Respondent 3, Respondent 5 also used videos in improving her own pronunciation 
skill. By watching related videos on teaching pronunciation, she believed that she will eventually improve her own pronunciation skill besides acquiring the correct pronunciation of difficult words. She also enjoyed listening to English songs that have proper and meaningful words. Similarly, Respondent 6 uses English songs as reference for the correct pronunciation of difficult words when she is teaching pronunciation.

The strategies used to manage external challenges in teaching pronunciation among the respondents in this study are shown in Table 1.6. Similar to the management of internal challenges, the themes found in the management of external challenges were the same which are to seek help and to plan for lessons.

Table 1.6 Managing external challenges in teaching pronunciation

\begin{tabular}{|c|c|c|}
\hline External challenges faced by the respondents & $\begin{array}{l}\text { Themes in } \\
\text { managing the } \\
\text { challenges }\end{array}$ & Summary of the response \\
\hline $\begin{array}{l}\text { Lack of teaching material and resources } \\
\text { Teaching materials are limited and not } \\
\text { really suitable for the students }\end{array}$ & - Seek help & $\begin{array}{l}\text { - Using online sources on creative ways } \\
\text { in teaching pronunciation }\end{array}$ \\
\hline $\begin{array}{l}\text { Lack of priority } \\
\text { - Teaching pronunciation is not emphasized in } \\
\text { schools }\end{array}$ & - Seek help & - Asking help from mentor \\
\hline $\begin{array}{l}\text { Limitation of time } \\
\text { - Time given for teaching English is not } \\
\text { enough }\end{array}$ & $\begin{array}{l}\text { - Prepare and } \\
\text { plan lessons }\end{array}$ & $\begin{array}{l}\text { - Integrating pronunciation teaching in } \\
\text { the teaching of other skills. E.g. } \\
\text { Reading comprehension }\end{array}$ \\
\hline
\end{tabular}

Based on Table 1.6, Respondent 3 preferred to look for online sources on creative ways to teach pronunciation since teaching materials are limited. This shows a reluctance to depend solely on the available sources and resources in the classroom such as textbook to teach her students. In addition, she believes that there are other ways that can be used in teaching pronunciation to her students such as conducting group work. On the other hand, Respondents 2 and 3 sought guidance from their mentors when faced with issue related to the lack of priority. They were uncertain if pronunciation is considered as an important skill to be taught and to be given priority in the classroom. As such, the decision to teach pronunciation as an embedded activity in a lesson was made after discussion with the mentor. Since class time is only adequate to cover a certain number of skills in one lesson, careful planning and management of lessons based on the syllabus are required at schools. Therefore, the teaching of pronunciation as an embedded activity in lessons rather than a whole lesson is considered the best option than teaching not teaching pronunciation at all. 
Based on the overall findings of how teacher trainees managed the problems they face when teaching pronunciation, there were only three out of six respondents who actually alluded to methodology on how to teach pronunciation. Having one-to-one sessions with the students will ensure the students feel comfortable during pronunciation lessons. Often students feel embarrassed if they mispronounce certain words. Therefore, if they could have one-to-one session with the teacher, they will feel secure and more interested to learn. This is supported by Varasin (2007) who stated that motivation is crucial in the process of learning and pronunciation learning is not excluded from having good motivation from the teacher. It is good practice for novice teachers to monitor closely their students' pronunciation skill by asking each student to practice pronouncing the words. Teachers can give attention to self-correction techniques and self-monitoring strategies in helping the students in developing the pronunciation (Varasarin, 2007). However, the teacher must refrain from directly correcting students' mistake in front of other students. It is applicable if the teacher could use classroom discussion in which teacher moves from one group to another to check on their pronunciation. To conclude, although novice teachers face both internal and external challenges in teaching pronunciation, they seem to employ three main methods in managing these challenges which are i) seek help, ii) prepare and plan lessons; and iii) devise strategies to help students. Based on these three themes, there are many possible solutions that can be used in managing these challenges.

\section{CONCLUSION}

In teaching pronunciation at schools, the teacher trainees in this study encountered both internal and external challenges. Internal challenges consist of i) lack of confidence, ii) lack of sufficient knowledge and iii) pedagogical issues. Often, respondents' fear of making mistakes in pronouncing words affected their confidence in teaching pronunciation to their students. In addition, novice teachers in this study also reported a lack of confidence in pronouncing certain words which also indicated their lack of knowledge of English pronunciation.

On the other hand, external challenges faced by novice teachers in this study included i) lack of priority, ii) limitation of time; and iii) lack of teaching materials and resources. Respondents were uncertain if pronunciation is considered as priority in teaching English to the students. Respondents also reported struggling with the time given to cover the required topics in the syllabus leaving them with little time teach pronunciation. Embedding pronunciation activity in the English lessons were considered the best option. In addition, teaching materials and other resources on pronunciation were found to be limited because of the individual differences and needs of each student. These challenges were the obstacles respondents faced by the teacher trainees in teaching pronunciation to students at school during their practical teaching.

The teacher trainees had their own ways in managing these challenges. The three main strategies emerged from the analysis of the interview data: i) seeking help, ii) coming out with a strategy and iii) helping the students. For the first strategy, respondents prefer to discuss issues or problems with their mentors and also use offline dictionary as reference. In contrast, when students face difficulties with 
pronouncing certain words, the respondents will devise a strategy to overcome the problem, for example, having one-to-to sessions with students. The respondents in this study also found that a Speak-Only-English rule in the classroom could help students practice their pronunciation. It is clear from the findings of this study that although novice teachers faced both internal and external challenges in teaching pronunciation, they showed a capacity to create different ways to manage these challenges. The management of these challenges showed that these novice teachers were aware of the importance of teaching pronunciation to the students and therefore did not allow these challenges to become a barrier.

\section{REFERENCES}

Baker, A. A. 2011. ESL Teachers and Pronunciation Pedagogy: Exploring the Development of Teachers' Cognitions and Classroom Practices. In J. Levis and K. LeVille (Eds.). Proceedings of the 2nd Pronunciation in Second Language Learning and Teaching Conference (pp. 82-94). Ames, IA: Iowa State University.

Ballard, K. 2013. The Framework of English: Introducing Language Structure. New York: Macmillan.

Barrera, P. 2013 Contextualized Pronunciation Teaching. Retrieved on 30 October, 2014, from http://dedi.uta.edu.ec/wpcontent/uploads/CONTEXTUALIZED\%20PRONUNCIATION\%20 TEACHING.pdf.

Breitkreutz, J., Derwing, T. M., and Rossiter, M. J. 2009. Pronunciation Teaching Practices in Canada. TESL Canada Journal. 19(1): 51-61.

Brindley, G. 1998. Outcomes-based Assessment and Reporting in Language Learning Programmes: A Review of the Issues. Language Testing. 15(1): 45-85.

Brown, A. 1992. A Survey of Attitudes and Teaching Practice Related to Pronunciation Teaching. Adult Multicultural Education Services, WA, Perth.

Couper, Graeme. 2017. Teacher Cognition of Pronunciation Teaching: Teachers' Concerns and Issues. TESOL Quarterly. 51(4): 820-843

Darcy, I., Ewert, D., and Lidster, R. 2011. Bringing Pronunciation Instruction Back into the Classroom: An ESL Teachers' Pronunciation Toolbox. Social Factors in Pronunciation Acquisition. 93.

Derwing, T. M., and Munro, M. J. 2005. Second Language Accent and Pronunciation Teaching: A Research-Based Approach. Tesol Quarterly. 39(3): 379-397.

Derwing, T., and Foote, J. 2011. National Survey of Pronunciation Teaching: Deja vu. Annual Association for Applied Linguistics. Chicago, IL.

Derwing, T. M., Diepenbroek, L. G. \& Foote, J. A. 2012. How Well do General-Skills ESL Textbooks Address Pronunciation? TESL Canada Journal. 30(1): 22-44. DOI: 10.18806/tesl.v30il.1124.

Egwuogu, C. B. 2012. Challenges and Techniques in the Teaching of English Pronunciation in Junior Secondary School in Nigeria. Asian Journal of Social Sciences and Humanities. 1(4): 212-219.

Elliot, A. R. 1995. Foreign Language Phonology: Field Independence, Attitude, and the Success of Formal Instruction in Spanish Pronunciation. The Modern Language Journal. 79(iv): 530-542. 
Farrell, T., \& Yang, D. M. 2017. Exploring an EAP Teacher's Beliefs and Practices Inteaching L2 Speaking: A Case Study. RELC Journal. 9: 1-14. https://doi.org/10.1177/0033688217730144.

Fraser, H. 2000. Coordinating Improvements in Pronunciation Teaching for Adultlearners of English as a Second Language. Canberra: DETYA (Australia National Training Authority Adult $\begin{array}{lllll}\text { Literacy } & \text { Project). } & \text { Retrieved } & \text { October } & \text { 2014, }\end{array}$ http://www.personal.une.edu.au/ hfraser/docs/HF_ANTA_REPORT.pdf.

Fraser, Helen 2002. Change, Challenge and Opportunity in Pronunciation and Oral Communication. Proceedings of the 15th annual EA education conference held at Canberra 10 - 12 October 2002. $\begin{array}{lllll}\text { Retrieved on } & \text { October } & 30, & \text { from }\end{array}$ http://trove.nla.gov.au/work/153103426?qandversionId=166856977.

Fraser, H. 2006. Helping Teachers Help Students with Pronunciation: A Cognitive Approach. Prospect: An Australian Journal of TESOL. 21(1): 78-94.

Georgios P. Georgiou. 2019. EFL Teachers' Cognitions about Pronunciation in Cyprus. Journal of Multilingual and Multicultural Development. 40(6): 538-550.

DOI: 10.1080/01434632.2018.1539090.

Gilbert, J. B. 2008. Teaching Pronunciation: Using the Prosody Pyramid. Cambridge University Press.

Gilakjani, A. P. 2012. A Study of Factors Affecting EFL Learners' English Pronunciation Learning and the Strategies for Instruction. International Journal of Humanities and Social Science. 2(3): 119-128.

Gilakjani, A. P., and Mohammad Reza Ahmadi 2011. Why is Pronunciation So Difficult to Learn? English Language Teaching: Canadian Center of Science and Education. 4(3): 74-83.

Grim, F., \& Sturm, J. 2016. Where Does Pronunciation Stand in the 21st Century Foreign Language Classroom? Educators' and Learners' Views. In J. Levis, H. Le, I. Lucic, E. Simpson, \& S. Vo (Eds). Proceedings of the $7^{\text {th }}$ Pronunciation in Second Language Learning and Teaching Conference, Dallas, TX, October, 2015 (pp. 51-59). Ames, IA: Iowa State University.

Gut, U. 2009. Introduction to English Phonetics and Phonology. Germany: Peter Language Corporation. Hayati A. Majid. 2008. Teaching English Pronunciation to Iranian Students: Problems and Suggestions. Retrieved on April 30, 2015, from http:/www.esljournal.org/62926768.html.

Jayapalan, K., and Pillai, S. 2011. The State of Teaching and Learning English Pronunciation in Malaysia: A Preliminary Study. Malaysian Journal of ELT Research. 7(2): 63-81.

M. Lekha Swarna Priya, Prasantha Kumar N S. 2020. Teaching Phonetics to Enhance Pronunciation in an ESL Classroom. Journal of Critical Reviews. 7(2): 669-672. Print. doi:10.31838/jer.07.02.121.

Macdonald, S. 2002. Pronunciation - views and practices of reluctant teachers. Prospect. 17(3): 3-15.

Macháčková, E. 2012. Teaching English Pronunciation to Secondary School Students with Focus on TH Consonants. Retrieved on 30 October, 2014, from http://is.muni.cz/th/183878/pedf_m/ the_final_thesis.pdf.

Mak, S. H. Y. 2011. Tensions between Conflicting Beliefs of an EFL Teacher in Teaching Practice. RELC Journal. 42(1): 53-67.

Morley, J. 1991. The Pronunciation Component in Teaching English to Speakers of Other Languages. TESOL Quarterly. 25(3): 481-520. 
Muhammed, A. A. and Taha, J. A. 2014. Segmental and Suprasegmental Difficulties in English Pronunciation to English as a Foreign Students (EFS) of English Department at Koya University. Retrieved on 30 October, 2014, from

http://univsul.edu.iq/Wenekan_KS/47302111112014_rerevised\%20journal\%20final\%20after\% 0feedback.pdf.

Nair, R., Krishnasamy, R., and De Mello, G. 2006. Rethinking the Teaching of Pronunciation in the ESL Classroom. The English Teacher. XXXV: 27-40.

Ndung'u, M. I. 2013. The Place of Authoritative and Plausible Reconstruction in the Interpretation and Assessment of Communicative English Proficiency among Secondary School Learners in Kenya. International Journal of Education and Research. 1(10).

Pillai, S. 2008. Speaking English the Malaysian Way - Correct or Not? English Today. 96(24/4): 42-45. Rogerson-Revell, P. 2011. English Phonology and Pronunciation Teaching. Bloomsbury Publishing.

Scrivener, J. 2005. Learning Teaching: The Essential Guide to English Language Teaching. Oxford, UK: Macmillan.

Shahzada, G. 2012. Views of the Teachers Regarding the Students' Poor Pronunciation in English Language. Journal of Educational and Social Research. 2(1).

Sukatan Pelajaran Kurikulum Bersepadu Sekolah Menengah. 2003. Pusat Perkembangan Kurikulum Kementerian Pendidikan Malaysia.

Varasarin, P. 2007. An Action Research Study of Pronunciation Training, Language Learning Strategies and Speaking Confidence. Doctoral dissertation, Victoria University. Retrieved on 30 October, 2014, from http://core.kmi.open.ac.uk/ download/pdf/10827059.pdf. 